\title{
Pemilihan Karyawan Terbaik Menggunakan Metode Profile Matching Pada PT. Surindo Murni Agung
}

\author{
Firdaus Idam $^{1}$, Agus Junaidi², Popon Handayani ${ }^{3}$ \\ ${ }^{1,3}$ Sekolah Tinggi Manajemen Informatika dan Komputer Nusa Mandiri \\ e-mail: ${ }^{1}$ firdausidam90@gmail.com, ${ }^{3}$ popon.pph@ nusamandiri.ac.id \\ ${ }^{2}$ Fakultas Teknologi Informasi, Universitas Bina Sarana Informatika \\ e-mail: agus.asj@bsi.ac.id
}

\begin{abstract}
Abstrak - Dalam penentuan karyawan terbaik di PT.Surindo Murni Agung Jakarta. Terdapat beberapa factor kriteria dalam pengambilan keputusan sehingga mendapatkan keputusan yang tepat. Kriteria nya adalah sikap kerja, kepribadian, dan tanggung jawab. Pada saat ini proses penilaian kinerja karyawan di PT.Surindo Murni Agung belum ada sehingga tidak dapat menentukan keputusan karyawan terbaik pada PT.Surindo Murni Agung Jakarta. Untuk Itu sistem pendukung keputusan (SPK) sangat membantu dalam hal pengambilan keputusan yang dibuat, kemudian dianalisis dengan menggunakan metode profile matching. Dengan menggunakan metode profile matching maka PT.Surindo Murni Agung Jakarta bisa membuat keputusan dalam penilaian kinerja karyawan yang sesuai dengan kemampuan. Penelitian ini adalah untuk mengetahui ranking/bobot nilai dalam penilaian karyawan terbaik di PT.Surindo Murni Agung Jakarta.
\end{abstract}

Kata Kunci: Penentuan karyawan terbaik; Sistem Pendukung Keputusan; Profile Matching

\begin{abstract}
In determining the best employees at PT.Surindo Murni Agung Jakarta. There are several criteria factors in making decisions so that getting the right decision. The criteria are work attitude, personality, and responsibility. At this time the employee performance appraisal process at PT.Surindo Murni Agung does not yet exist so it cannot determine the best employee decisions at PT.Surindo Murni Agung Jakarta. For that decision support system (SPK) is very helpful in terms of decision making made, then analyzed using the profile matching method. By using the profile matching method, PT.Surindo Murni Agung Jakarta can make decisions in evaluating employee performance according to ability. This study is to determine the ranking / weight value in the assessment of the best employees at PT. Surindo Murni Agung Jakarta
\end{abstract}

Keywords: Best Employee Selection; Decision support system; Profile Matching

\section{PENDAHULUAN}

Untuk mengambil sebuah keputusan tentu di perlukan analisis-analisis dalam perhitungan yang matang, tergantung dengan banyak atau sedikitnya kriteria yang mempengaruhi permasalahan yang membutuhkan suatu keputusan. Pengambilan suatu keputusan dengan banyak kriteria memerlukan suatu cara penanganan khusus terutama bila kriteria pengambilan keputusan tersebut saling terkait. Untuk itu dibutuhkan suatu model keputusan penilaian yang akan diambil pada PT.Surindo Murni Agung. Faktor peilaian tersebut terdiri dari penilaian kinerja,sikap kerja, dan kerja sama team, hasil kerja dan kedisiplinan.

Menurut Budiarjo, 2015 Dalam (Heru, 2017) Sumber daya manusia yang dimiliki perusahaan haruslah SDM yang berkualitas. Salah satu cara memperoleh SDM yang berkualitas tadi dapat melalui upaya penilaian kinerja karyawan. Dalam kehidupan sehari-hari manusia sering dihadapkan pada pilihan untuk mengambil sebuah keputusan. Kemampuan mengambil keputusan yang cepat dan cermat akan menjadi kunci keberhasilan dalam persaingan global.

Menurut Firdaus, Abdillah, \& Renaldi, 2016 dalam (Hertyana, 2018) "Karyawan merupakan salah satu aset terpenting yang dimiliki oleh perusahaan dalam usahanya mempertahankan kelangsungan hidup, berkembang, kemampuan untuk bersaing serta mendapatkan laba".

Aset-aset lain yang dimiliki oleh perusahaan seperti modal, bangunan, mesin, peralatan kantor, persediaan barang, dan lainnya, namun hanya karyawan lah yang dapat bernapas, berpikir, merasa, dan berperilaku. Keunikan ini jika memiliki kualitas yang baik dan dilibatkan dalam aktifitas usaha akan memberikan sumbangan yang besar bagi kemajuan perusahaan. Pada umumnya perusahaan kesulitan dalam mendapatkan karyawan yang baik dan berkualitas untuk posisi jabatan yang dibutuhkan.

Pada saat ini proses penilaian kinerja karyawan di PT. Surindo Murni Agung masih belum ada sehingga tidak bisa menentukan karyawan terbaik. Untuk mengatasi permasalahan yang ada, maka dibuatkan suatu sistem pendukung keputusan menggunakan metode Profile Matching. Metode ini 
dipilih agar dapat menghasilkan data terbaik karna dilakukan dengan mencari nilai bobot setiap individu dan diharapkan dapat membantu melakukan proses penilaian kepada siswa berprestasi sehingga hasil yang di dapat lebih efektif dan efisien.

Menurut Puspitasari, 2013 dalam (Nashrullah dkk, 2015) Profile Matching merupakan proses membandingkan antara kompetensi individu ke dalam kompetensi jabatan sehingga dapat diketahui perbedaan kompetensinya (disebut juga gap), Semakin kecil gap yang dihasilkan maka bobot nilainya semakin besar berarti memiliki peluang lebih besar untuk karyawan menempati posisi tersebut. Profile Matching merupakan suatu proses yang sangat penting dalam manajemen SDM di mana terlebih dahulu ditentukan kompetensi (kemampuan) yang diperlukan oleh suatu jabatan. Kompetensi kemampuan tersebut haruslah dapat dipenuhi oleh pemegang atau calon yang akan dinilai kinerjanya.

Menurut (Haryani \& Fitriani, 2019) Decision Support System (DSS) atau Sistem Pendukung Keputusan (SPK) menjelaskan bahwa :sistem informasi interaktif yang menyediakan informasi, pemodelan dan pemanipulasian data. Sistem tersebut digunakan untuk membantu mengambil keputusan dalam situasi semi terstruktur dan situasi tidak terstruktur, di mana tak seorang pun tahu cara pasti bagaimana keputusan seharusnya dibuat.

Menurut Turban, Rainer, Potter 2015: 321 dalam (Helilintar, Winarno, \& Fatta, 2016) menyebutkan bahwa Sistem Pendukung Keputusan adalah suatu sistem informasi berbasis computer mengkombinasikan model dan data untuk menyediakan dukungan kepada pengambil keputusan dalam memecahkan masalah semiterstruktur atau masalah ketergantungan yang melibatkan user secara mendalam.

Menurut Kusrini, 2007 dalam (Hidayat, 2016) "Metode Profile Matching atau pencocokan profil adalah metode yang sering sebagai mekanisme dalam pengambilan keputusan dengan mengasumsikan bahwa terdapat tingkat variabel prediktor yang ideal yang harus dipenuhi oleh subyek yang diteliti, bukannya tingkat minimal yang harus dipenuhi atau dilewati”.

Menurut (Puspitasari, 2013) dalam (Nashrullah dkk, 2015) Profile Matching merupakan proses membandingkan antara kompetensi individu ke dalam kompetensi jabatan sehingga dapat diketahui perbedaan kompetensinya (disebut juga gap), Semakin kecil gap yang dihasilkan maka bobot nilainya semakin besar berarti memiliki peluang lebih besar untuk karyawan menempati posisi tersebut. Profile Matching merupakan suatu proses yang sangat penting dalam manajemen SDM di mana terlebih dahulu ditentukan kompetensi (kemampuan) yang diperlukan oleh suatu jabatan. Kompetensi kemampuan tersebut haruslah dapat dipenuhi oleh pemegang atau calon yang akan dinilai kinerjanya.

Penelitian sebelumnya tentang beasiswa adalah "Selama ini proses penentuan penerima beasiswa hanya dilihat dari nilai rapot, dan tidak menggunakan penilaian lain untuk menentukan berhak atau tidaknya siswa tersebut memperoleh beasiswa, oleh karena itu untuk membantu penentuan dalam menetapkan siswa yang layak menerima beasiswa maka dibutuhkan sebuah analisa terkait siapa saja siswa yang menerima beasiswa tersebut. Salah satu metode yang dapat penulis gunakan untuk analisa keputusan ini adalah dengan menggunakan pencocokan profile (profile matching). Metode ini dipilih karena membantu yayasan Ad-Da'wah Jakarta memberikan beasiswa kepada siswa yang layak mendapatkan beasiswa" (Junaidi \& Visella, 2017)

\section{METODOLOGI PENELITIAN}

Tahapan dalam penelitian ini dapat ditunjukkan dalam gambar 1

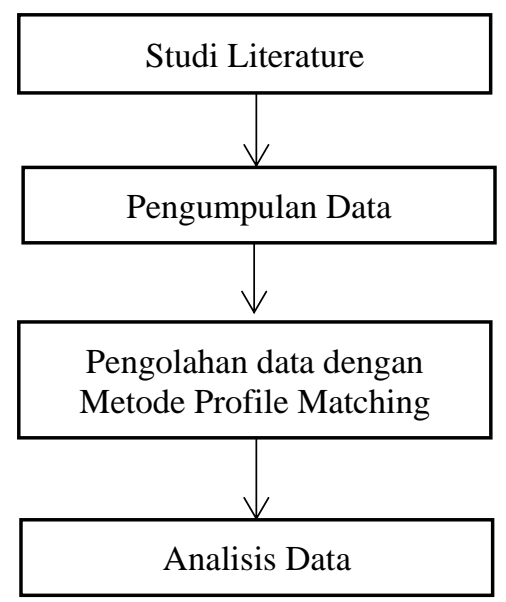

Gambar 1. Tahapan penelitian

Menjelaskan kronologis penelitian, termasuk desain penelitian, prosedur penelitian (dalam bentuk algoritma, Pseudocode atau lainnya), bagaimana untuk menguji dan akuisisi data. Deskripsi dari program penelitian harus didukung referensi, sehingga penjelasan tersebut dapat diterima secara ilmiah.

Dalam pengumpulan data untuk mendukung penelitian penulis melakukan :

A. Observasi

Penulis melakukan pengamatan dan penelitian secara langsung dengan cara melakukan riset langsung ke PT. Surindo Murni Agung yang beralamat pada Jl. Basoka Raya No. 6 B Joglo, Jakarta Barat. Kegiatan ini dilakukan agar mendapatkan data dengan akurasi yang sangat tepat.

B. Wawancara 
Dalam punulisan ini, untuk mendapatkan informasi secara lengkap maka penulis melakukan wawancara langsung mengenai semua kegiatan yang berhubungan dengan pemilihan karyawan terbaik. Adapun narasumber yang terkait dalam sesi wawancara itu adalah Bapak Zalmi Rais selaku HRD (Human Resources Development). .

C. Studi Pusaka

Studi Pustaka digunakan penulis untuk menghimpun informasi yang relevan dengan topik masalah yang sedang di teliti melalui literatur-literatur atau referensi-referensi yang ada di perpustakaan, internet, dan e-journal.

Analisis data dilakukan dengan menggunakan responden sebanyak 30 karyawan yang terdapat pada PT. Surindo Murni Agung dengan kriteria seperti terlihat pada tabel 1 .

Tabel 1. Usia Responden

\begin{tabular}{|l|c|}
\hline \multicolumn{1}{|c|}{ Usia } & Jumlah \\
\hline $20-30$ tahun & 15 orang \\
\hline $31-40$ tahun & 13 orang \\
\hline $41-50$ tahun & 2 orang \\
\hline Total & 30 orang \\
\hline
\end{tabular}

\section{HASIL DAN PEMBAHASAN}

Aspek-aspek yang digunakan untuk pemilihan karyawan berprestasi adalah:

\section{A. Aspek kriteria dan bobot nilai}

Tabel 2. Aspek Kriteria dan Bobot Nilai

\begin{tabular}{|c|c|c|c|}
\hline No & Kriteria & Sub Kriteria & $\begin{array}{l}\text { Bobot } \\
\text { Nilai }\end{array}$ \\
\hline \multirow{3}{*}{1} & \multirow{3}{*}{$\begin{array}{c}\text { Aspek } \\
\text { Sikap kerja }\end{array}$} & Kejujuran & \multirow{3}{*}{$40 \%$} \\
\hline & & Kemampuan & \\
\hline & & Ketelitian & \\
\hline \multirow{3}{*}{2} & \multirow{3}{*}{$\begin{array}{c}\text { Aspek } \\
\text { Kepribadian }\end{array}$} & Kepatuhan & \multirow{3}{*}{$30 \%$} \\
\hline & & Penampilan & \\
\hline & & Perilaku & \\
\hline \multirow{3}{*}{3} & \multirow{3}{*}{$\begin{array}{l}\text { Aspek } \\
\text { Tanggung } \\
\text { Jawab }\end{array}$} & $\begin{array}{ll}\text { Kehadiran } & \text { tepat } \\
\text { waktu }\end{array}$ & \multirow{3}{*}{$30 \%$} \\
\hline & & $\begin{array}{l}\text { Ketetapan waktu } \\
\text { dalam } \\
\text { menyelesaikan tugas }\end{array}$ & \\
\hline & & $\begin{array}{l}\text { Penerimaan tugas } \\
\text { tambahan }\end{array}$ & \\
\hline
\end{tabular}

B. Klasifikasi Core Factor dan Secondary Factor

Setelah menentukan nilai bobot gap untuk ketiga aspek yaitu aspek sikap kerja, perilaku dan produktivitas. Kemudian setiap aspek dikelompokkan menjadi 2 kelompok yaitu core factor dan secondary factor

Tabel 3. Core Factor dan secondary factor

\begin{tabular}{|c|c|c|c|}
\hline NO & Aspek & Core & Secondary \\
\hline \multirow{2}{*}{1} & \multirow{2}{*}{ Sikap Kerja } & Kejujuran & Kemampuan \\
\hline & & Ketelitian & \\
\hline \multirow{2}{*}{2} & \multirow{2}{*}{ Kepribadian } & Kepatuhan & Penampilan \\
\hline & & Perilaku & \\
\hline \multirow{2}{*}{3} & \multirow{2}{*}{$\begin{array}{l}\text { Tanggung } \\
\text { Jawab }\end{array}$} & $\begin{array}{l}\text { Kehadiran tetap } \\
\text { waktu }\end{array}$ & $\begin{array}{l}\text { Penerimaan } \\
\text { tugas } \\
\text { tambahan }\end{array}$ \\
\hline & & $\begin{array}{l}\text { Tepat waktu saat } \\
\text { menyelesaikan } \\
\text { tugas }\end{array}$ & \\
\hline
\end{tabular}

Perhitungan pemetaan gap kompetensi di paparkan tiap aspeknya pada tabel 4 :

Tabel 4. Aspek Sikap Kerja

\begin{tabular}{|l|l|c|c|c|}
\hline No & \multicolumn{1}{|c|}{ Nama karyawan } & \multicolumn{3}{|c|}{ Sikap Kerja } \\
\cline { 3 - 5 } & & $\begin{array}{l}\text { SK } \\
1\end{array}$ & $\begin{array}{l}\text { SK } \\
2\end{array}$ & $\begin{array}{l}\text { SK } \\
3\end{array}$ \\
\hline 1 & $\begin{array}{l}\text { Devin Baguskara } \\
\text { putra }\end{array}$ & 4 & 3 & 4 \\
\hline 2 & Novianti Saputri & 4 & 4 & 4 \\
\hline 3 & Judistina Tyas & 5 & 5 & 4 \\
\hline 4 & Sonny & 4 & 4 & 3 \\
\hline 5 & $\begin{array}{l}\text { Fajar Deddy } \\
\text { Hidayah }\end{array}$ & 3 & 3 & 4 \\
\hline Profile Kriteria & $\mathbf{5}$ & $\mathbf{4}$ & $\mathbf{5}$ \\
\hline 1 & $\begin{array}{l}\text { Devin Baguskara } \\
\text { putra }\end{array}$ & -1 & -1 & -1 \\
\hline 2 & Novianti Saputri & -1 & 0 & -1 \\
\hline 3 & Judistina Tyas & 0 & 1 & -1 \\
\hline 4 & Sonny & -1 & 0 & -2 \\
\hline 5 & $\begin{array}{l}\text { Fajar } \\
\text { Hidayah Deddy }\end{array}$ & -2 & -1 & -1 \\
\hline
\end{tabular}

Sumber : PT.Surindo Murni Agung

Tabel 5. Aspek Kepribadian

\begin{tabular}{|l|l|c|c|c|}
\hline No & Nama karyawan & \multicolumn{3}{|c|}{ Kepribadian } \\
\cline { 2 - 5 } & & KB1 & KB2 & KB3 \\
\hline 1 & $\begin{array}{l}\text { Devin Baguskara } \\
\text { putra }\end{array}$ & 5 & 5 & 4 \\
\hline 2 & Novianti Saputri & 4 & 4 & 4 \\
\hline 3 & Judistina Tyas & 5 & 3 & 5 \\
\hline 4 & Sonny Deddy & 4 & 4 & 5 \\
\hline 5 & $\begin{array}{l}\text { Fajar } \\
\text { Hidayah }\end{array}$ & 5 & 4 & 4 \\
\hline \multicolumn{2}{|c|}{ Profile Kinerja } & $\mathbf{5}$ & $\mathbf{3}$ & $\mathbf{5}$ \\
\hline
\end{tabular}




\begin{tabular}{|l|l|c|c|c|}
\hline 1 & $\begin{array}{l}\text { Devin Baguskara } \\
\text { putra }\end{array}$ & 0 & 2 & -1 \\
\hline 2 & Novianti Saputri & -1 & 1 & -1 \\
\hline 3 & Judistina Tyas & 0 & 0 & 0 \\
\hline 4 & Sonny & -1 & 1 & 0 \\
\hline 5 & $\begin{array}{l}\text { Fajar Deddy } \\
\text { Hidayah }\end{array}$ & 0 & 1 & -1 \\
\hline
\end{tabular}

Sumber : PT.Surindo Murni Agung

Tabel 6. Aspek Tanggung Jawab

\begin{tabular}{|l|l|c|c|c|}
\hline \multirow{2}{*}{ No } & Nama Karyawan & \multicolumn{3}{|c|}{ Tanggung Jawab } \\
\cline { 2 - 5 } & & TJ1 & TJ2 & TJ03 \\
\hline 1 & $\begin{array}{l}\text { Devin Baguskara } \\
\text { putra }\end{array}$ & 5 & 4 & 4 \\
\hline 2 & Novianti Saputri & 4 & 4 & 3 \\
\hline 4 & $\begin{array}{l}\text { Judistina Tyas } \\
\text { Sonny Deddy }\end{array}$ & 4 & 4 & 4 \\
\hline 5 & $\begin{array}{l}\text { Fajar } \\
\text { Hidayah Priteria }\end{array}$ & 5 & 4 & 4 \\
\hline 1 & $\begin{array}{l}\text { Profile Kevin Baguskara } \\
\text { putra }\end{array}$ & 0 & -1 & -1 \\
\hline 2 & Novianti Saputri & -1 & -1 & -2 \\
\hline 3 & $\begin{array}{l}\text { Judistina Tyas } \\
\text { Jonny Deddy }\end{array}$ & -1 & -1 & -1 \\
\hline 4 & Sonn & -2 & -2 & -3 \\
\hline 5 & $\begin{array}{l}\text { Fajar } \\
\text { Hidayah }\end{array}$ & 0 & -1 \\
\hline
\end{tabular}

Sumber : Hasil PT.Surindo Murni Agung

C. Bobot Nilai Gap Aspek Disiplin

Setelah didapatkan tiap gap masing karyawan tiap profil karyawan diberi bobot nilai dengan patokan tabel bobot nilai gap. Tiap karyawan akan memiliki tabel bobot nilai dengan acuan pada tabel nilai gap. Maka karyawan dengan sub-sub aspek sikap kerja, kepribadian, tanggung jawab akan memiliki hasil dengan bobot nilai gap seperti terlihat pada tabel 7 .

Tabel 7. Bobot Nilai Gap Sikap Kerja

\begin{tabular}{|l|l|c|c|c|}
\hline \multirow{2}{*}{ No } & \multirow{2}{*}{ Nama Karyawan } & \multicolumn{3}{|c|}{ Sikap Kerja } \\
\cline { 2 - 5 } & & SK1 & SK2 & SK3 \\
\hline 1 & $\begin{array}{l}\text { Devin Baguskara } \\
\text { putra }\end{array}$ & -1 & -1 & -1 \\
\hline 2 & Novianti Saputri & -1 & 0 & -1 \\
\hline 3 & Judistina Tyas & 0 & 1 & -1 \\
\hline 4 & Sonny Nilai Bobot & -1 & 0 & -2 \\
\hline 5 & \multicolumn{5}{|c|}{ Fajar Deddy Hidayah } & -2 & -1 & -1 \\
\hline \multicolumn{5}{|c|}{ Baguskara } \\
\hline 1 & $\begin{array}{l}\text { Devin } \\
\text { putra }\end{array}$ & 4 & 4 \\
\hline 2 & Novianti Saputri & 4 & 5 & 4 \\
\hline 3 & Judistina Tyas & 5 & 4,5 & 4 \\
\hline 4 & Sonny & 4 & 5 & 3 \\
\hline 5 & Fajar Deddy Hidayah & 3 & 4 & 4 \\
\hline
\end{tabular}

Sumber : Hasil PT.Surindo Murni Agung
Tabel 8. Bobot Nilai Gap Aspek Kepribadian

\begin{tabular}{|l|l|r|r|r|}
\hline No & Nama Karyawan & \multicolumn{3}{|c|}{ Variabel } \\
\cline { 3 - 5 } & & KB1 & KB2 & KB3 \\
\hline 1 & $\begin{array}{l}\text { Devin Baguskara } \\
\text { putra }\end{array}$ & 0 & 2 & -1 \\
\hline 2 & Novianti Saputri & -1 & 1 & -1 \\
\hline 3 & Judistina Tyas & 0 & 0 & 0 \\
\hline 4 & Sonny Deddy & -1 & 1 & 0 \\
\hline 5 & $\begin{array}{l}\text { Fajar } \\
\text { Hidayah }\end{array}$ & & \\
\hline \multicolumn{5}{|l|}{ Bobot Nilai } \\
\hline 1 & $\begin{array}{l}\text { Devin Baguskara } \\
\text { putra }\end{array}$ & 5 & 3,5 & 4 \\
\hline 2 & Novianti Saputri & 4 & 4,5 & 4 \\
\hline 3 & Judistina Tyas & 5 & 5 & 5 \\
\hline 4 & Sonny Deddy & 4 & 4,5 & 5 \\
\hline 5 & $\begin{array}{l}\text { Fajar } \\
\text { Hidayah }\end{array}$ & 5 & 4,5 & 4 \\
\hline
\end{tabular}

Sumber : Hasil PT.Surindo Murni Agung

Tabel 9. Bobot Nilai Gap Aspek Tanggung Jawab

\begin{tabular}{|c|l|c|c|c|}
\hline No & \multicolumn{1}{|c|}{ Nama Karyawan } & \multicolumn{3}{|c|}{ Variabel } \\
\cline { 2 - 5 } & \multicolumn{1}{|c|}{ TJ1 } & TJ2 & TJ3 \\
\hline 1 & $\begin{array}{l}\text { Devin Baguskara } \\
\text { putra }\end{array}$ & 0 & -1 & 0 \\
\hline 2 & Novianti Saputri & 0 & 0 & 1 \\
\hline 3 & Judistina Tyas & -1 & -1 & 0 \\
\hline 4 & Sonny Deddy & -1 & 0 & 1 \\
\hline 5 & $\begin{array}{l}\text { Fajar } \\
\text { Hidayah Nilai Bobot }\end{array}$ & 0 & 0 \\
\hline \multicolumn{5}{|c|}{ Baguskara } \\
1
\end{tabular}

Sumber : PT.Surindo Murni Agung

D. Perhitungan Core Factor dan Secondary Factor

Perhitungan Core factor dan secondary factor untuk aspek disiplin, core factor untuk aspek Sikap kerja adalah SK1 dan SK3. Kemudian secondary factor dari aspek disiplin adalah SK2. Kemudian nilai core factor dan secondary factor dijumlahkan sesuai rumus dan hasilnya ditampilkan pada Tabel 10. 
Tabel 10. Nilai Aspek NCF dan NSF kriteria Sikap Kerja

\begin{tabular}{|c|c|c|c|c|c|c|}
\hline \multirow[t]{2}{*}{ No } & \multirow[t]{2}{*}{ Karyawan } & \multicolumn{5}{|c|}{ Sikap kerja } \\
\hline & & $\begin{array}{l}\text { SK } \\
1\end{array}$ & SK2 & $\begin{array}{l}\text { SK } \\
3\end{array}$ & NCF & $\begin{array}{l}\text { NS } \\
\text { F }\end{array}$ \\
\hline 1 & $\begin{array}{l}\text { Devin } \\
\text { Baguskara } \\
\text { putra }\end{array}$ & -1 & -1 & -1 & 4 & 4 \\
\hline 2 & $\begin{array}{l}\text { Novianti } \\
\text { Saputri }\end{array}$ & -1 & 0 & -1 & 4 & 5 \\
\hline 3 & Judistina Tyas & 0 & 1 & -1 & 4,5 & $\begin{array}{c}4, \\
5 \\
\end{array}$ \\
\hline 4 & Sonny & -1 & 0 & -2 & 3,5 & 5 \\
\hline 5 & $\begin{array}{l}\text { Fajar Deddy } \\
\text { Hidayah }\end{array}$ & -2 & -1 & -1 & 3,5 & 4 \\
\hline
\end{tabular}

Sumber : Hasil pengolahan data (2019)

Berikut core factor dari aspek kedisiplinan yaitu KB1 dan KB3. Dan secondary factor KB2. Kemudian nilai core factor dan secondary factor di jumlahkan sesuai rumus dan hasilnya ditampilkan pada tabel 11 .

Tabel 11. Nilai Aspek NCF dan NSF kriteria Kepribadian

\begin{tabular}{|c|c|c|c|c|c|c|}
\hline \multirow{2}{*}{$\begin{array}{l}\mathrm{N} \\
\mathrm{O}\end{array}$} & \multirow{2}{*}{$\begin{array}{c}\text { Karyaw } \\
\text { an }\end{array}$} & \multicolumn{5}{|c|}{ Variabel } \\
\hline & & KB1 & $\mathrm{KB} 2$ & KB3 & $\mathrm{NCF}$ & NSF \\
\hline 1 & $\begin{array}{l}\text { Devin } \\
\text { Baguska } \\
\text { ra putra }\end{array}$ & 5 & 3,5 & 4 & 4,5 & 3,5 \\
\hline 2 & $\begin{array}{l}\text { Noviant } \\
\text { i Saputri }\end{array}$ & 4 & 4,5 & 4 & 4 & 4,5 \\
\hline 3 & $\begin{array}{l}\text { Judistin } \\
\text { a Tyas }\end{array}$ & 5 & 5 & 5 & 5 & 5 \\
\hline 4 & Sonny & 4 & 4,5 & 5 & 4,5 & 4,5 \\
\hline 5 & $\begin{array}{l}\text { Fajar } \\
\text { Deddy } \\
\text { Hidayah }\end{array}$ & 5 & 4,5 & 4 & 4,5 & 4,5 \\
\hline
\end{tabular}

Sumber : Hasil pengolahan data (2019)

Perhitungan Core factor dan secondary factor untuk aspek tanggung jawab, core factor untuk aspek tanggung jawab adalah TJ1 dan TJ2. Kemudian secondary factor dari aspek disiplin adalah TJ3. Kemudian nilai core factor dan secondary factor dijumlahkan sesuai rumus dan hasilnya ditampilkan pada Tabel 12.

Tabel 12. Nilai Aspek NCF dan NSF Untuk Kriteria Tanggung Jawab

\begin{tabular}{|l|c|c|c|c|c|c|}
\hline \multirow{2}{*}{$\begin{array}{l}\text { N } \\
\mathrm{o}\end{array}$} & \multirow{2}{*}{ Karyawan } & \multicolumn{5}{|c|}{ Tanggung Jawab } \\
\cline { 3 - 7 } & & $\begin{array}{c}\text { TJ } \\
1\end{array}$ & $\begin{array}{c}\text { TJ } \\
2\end{array}$ & $\begin{array}{c}\text { Tj } \\
3\end{array}$ & NCF & NSF \\
\hline 1 & $\begin{array}{l}\text { Devin } \\
\text { putra }\end{array}$ & 5 & 4 & 5 & 4,5 & 5 \\
\hline
\end{tabular}

\begin{tabular}{|l|l|c|c|c|c|c|}
\hline 2 & Novianti Saputri & 5 & 5 & 5 & 5 & 4,5 \\
\hline 3 & Judistina Tyas & 4 & 4 & 5 & 4 & 5 \\
\hline 4 & Sonny & 4 & 5 & $\begin{array}{r}4, \\
\text { Fajar Deddy }\end{array}$ & 4,5 & 4,5 \\
\hline 5 & $\begin{array}{l}\text { Hidayah } \\
\text { Hajar }\end{array}$ & 5 & 5 & 5 & 5 \\
\hline
\end{tabular}

Sumber : Hasil pengolahan data (2019)

\section{E. Perhitungan Nilai Total}

Dari Hasil perhitungan dari tiap aspek kemudian dihitung nilai total core dan secondary yang diperkirakan berpengaruh terhadap kinerja tiap-tiap profil. Penghitungan nilai total terlebih dahulu menentukan nilai persen yang diinputkan, core factor $60 \%$ dan secondary factor $40 \%$. Kemudian nilai core factor dan secondary factor dijumlahkan sesuai rumus dan hasilnya dapat dilihat dibawah pada perhitungan Aspek Disiplin, Aspek Kerjasama, Aspek Prestasi kerja dan Aspek hasil kerja yang ditampilkan pada Tabel 13, Tabel 14, dan Tabel 15.

Tabel 13. Nilai Total Aspek Sikap Kerja

\begin{tabular}{|c|c|c|c|c|}
\hline $\begin{array}{l}\mathrm{N} \\
\mathrm{o}\end{array}$ & $\begin{array}{c}\text { Karyawa } \\
\mathrm{n}\end{array}$ & $\begin{array}{c}\mathrm{NC} \\
\mathrm{F}\end{array}$ & $\begin{array}{c}\mathrm{NS} \\
\mathrm{F}\end{array}$ & Ds \\
\hline 1 & $\begin{array}{l}\text { Devin } \\
\text { Baguska } \\
\text { ra putra }\end{array}$ & 4 & 4 & $\begin{array}{c}(60 \% * 4)+(40 \% * 4)= \\
4,0\end{array}$ \\
\hline 2 & $\begin{array}{l}\text { Novianti } \\
\text { Saputri }\end{array}$ & 4 & 5 & $\begin{array}{c}(60 \% * 4)+(40 \% * 5)= \\
4,4\end{array}$ \\
\hline 3 & $\begin{array}{l}\text { Judistina } \\
\text { Tyas }\end{array}$ & 4,5 & 4,5 & $\begin{array}{c}(60 \% * 4,5)+(40 \% * 4,5) \\
=4,5\end{array}$ \\
\hline 4 & Sonny & 3,5 & 5 & $\begin{array}{c}(60 \% * 3,5)+(40 \% * 5)=4 \\
, 1\end{array}$ \\
\hline 5 & $\begin{array}{l}\text { Fajar } \\
\text { Deddy } \\
\text { Hidayah }\end{array}$ & 3,5 & 4 & $\begin{array}{c}(60 \% * 3,5)+(40 \% * 4)=3 \\
, 7\end{array}$ \\
\hline
\end{tabular}

Sumber : Hasil pengolahan data(2019)

Tabel 14. Nilai Total Aspek Kepribadian

\begin{tabular}{|c|l|c|c|c|}
\hline $\begin{array}{c}\mathrm{N} \\
\mathrm{o}\end{array}$ & $\begin{array}{l}\text { Karyawa } \\
\mathrm{n}\end{array}$ & $\begin{array}{c}\mathrm{NC} \\
\mathrm{F}\end{array}$ & $\begin{array}{c}\mathrm{NS} \\
\mathrm{F}\end{array}$ & $\mathrm{Ks}$ \\
\hline 1 & $\begin{array}{l}\text { Devin } \\
\text { Baguskar } \\
\text { a putra }\end{array}$ & 4,5 & 3,5 & $\begin{array}{c}(60 \% * 4,5)+(40 \% * 3, \\
5)=4,1\end{array}$ \\
\hline 2 & $\begin{array}{l}\text { Novianti } \\
\text { Saputri }\end{array}$ & 4 & 4,5 & $\begin{array}{c}(60 \% * 4)+(40 \% * 4,5) \\
=4,2\end{array}$ \\
\hline 3 & $\begin{array}{l}\text { Judistina } \\
\text { Tyas }\end{array}$ & 5 & 5 & $\begin{array}{c}(60 \% * 5)+(40 \% * 5) \\
=5\end{array}$ \\
\hline 4 & Sonny & 4,5 & 4,5 & $\begin{array}{c}(60 \% * 4,5)+(40 \% * 4, \\
5)=4,5\end{array}$ \\
\hline 5 & $\begin{array}{l}\text { Fajar } \\
\text { Deddy } \\
\text { Hidayah }\end{array}$ & 4,5 & 4,5 & $\begin{array}{c}(60 \% * 4,5)+(40 \% * 4, \\
5)=4,5\end{array}$ \\
\hline
\end{tabular}

Sumber : Hasil pengolahan data (2019) 
Tabel 15. Nilai Total Aspek Tanggung Jawab

\begin{tabular}{|c|l|c|c|c|}
\hline $\begin{array}{c}\text { N } \\
\text { o }\end{array}$ & $\begin{array}{l}\text { Karyawa } \\
\text { n }\end{array}$ & $\begin{array}{c}\text { NC } \\
\text { F }\end{array}$ & $\begin{array}{c}\text { NS } \\
\text { F }\end{array}$ & Ks \\
\hline 1 & $\begin{array}{l}\text { Devin } \\
\text { Baguskar } \\
\text { a putra }\end{array}$ & 4,5 & 5 & $\begin{array}{c}(60 \% * 4,5)+(40 \% * 5) \\
=4,7\end{array}$ \\
\hline 2 & $\begin{array}{l}\text { Novianti } \\
\text { Saputri }\end{array}$ & 5 & 4,5 & $\begin{array}{c}(60 \% * 5)+(40 \% * 4,5) \\
=4,8\end{array}$ \\
\hline 3 & $\begin{array}{l}\text { Judistina } \\
\text { Tyas }\end{array}$ & 4 & 5 & $\begin{array}{c}(60 \% * 4)+(40 \% * 5) \\
=4,4\end{array}$ \\
\hline 4 & Sonny & 4,5 & 4,5 & $\begin{array}{c}(60 \% * 4,5)+(40 \% * 4, \\
5)=4,5\end{array}$ \\
\hline 5 & $\begin{array}{l}\text { Fajar } \\
\text { Deddy } \\
\text { Hidayah }\end{array}$ & 5 & 5 & $\begin{array}{c}(60 \% * 5)+(40 \% * 5)= \\
5\end{array}$ \\
\hline
\end{tabular}

Sumber : Hasil pengolahan data (2019)

F. Total nilai seluruh aspek kriteria yang ada

Tabel 16 berisi hasil perhitungan dari aspek sikap kerja, aspek kepribadian, dan aspek tanggung jawab pada setiap karyawan pada PT.Surindo Murni Agung

Tabel 16. Nilai Keseluruhan Aspek Sikap Kerja

\begin{tabular}{|l|l|c|c|c|c|}
\hline \multirow{2}{*}{ No } & \multirow{2}{*}{ Karyawan } & \multicolumn{4}{|c|}{ Total Nilai } \\
\cline { 3 - 6 } & & NSK & NKB & NTJ & NHK \\
\hline 1 & $\begin{array}{l}\text { Devin } \\
\text { Baguskara } \\
\text { putra }\end{array}$ & 4,0 & 4,1 & -1 & 4,7 \\
\hline 2 & $\begin{array}{l}\text { Novianti } \\
\text { Saputri }\end{array}$ & 4,4 & 4,2 & -1 & 4,8 \\
\hline 3 & $\begin{array}{l}\text { Judistina } \\
\text { Tyas }\end{array}$ & 4,5 & 5 & -1 & 4,4 \\
\hline 4 & Sonny & 4,1 & 4,5 & -2 & 4,5 \\
\hline 5 & $\begin{array}{l}\text { Fajar Deddy } \\
\text { Hidayah }\end{array}$ & 3,7 & 4,5 & -1 & 5 \\
\hline
\end{tabular}

Sumber : Hasil pengolahan data(2019)

Tabel 17 adalah hasil perhitungan perangkingan seluruh karyawan pada PT.Surindo Murni Agung

Tabel 17. Nilai Total Aspek Sikap Kerja

\begin{tabular}{|c|c|c|c|c|c|c|c|}
\hline \multirow{2}{*}{ Nama } & \multirow{2}{*}{$\begin{array}{c}\mathrm{N} \\
1\end{array}$} & \multirow{2}{*}{$\begin{array}{l}\mathrm{N} \\
2\end{array}$} & \multirow{2}{*}{$\begin{array}{l}\mathrm{N} \\
3\end{array}$} & \multicolumn{3}{|c|}{ PRESENTASE } & \multirow{2}{*}{$\begin{array}{c}\text { HASI } \\
\mathrm{L} \\
\text { AKHI } \\
\mathrm{R} \\
\\
\mathrm{N} 1+\mathrm{N} \\
2+\mathrm{N} 3 \\
\end{array}$} \\
\hline & & & & $\begin{array}{l}40 \\
\% * \\
\mathrm{~N} 1\end{array}$ & $\begin{array}{l}30 \\
\% * \\
\text { N2 }\end{array}$ & $\begin{array}{c}30 \\
\% * \\
\text { N3 }\end{array}$ & \\
\hline Devin & 4 & 4 & 4 & & & & \\
\hline Baguska & 0 & 1 & 7 & 1,6 & 1,2 & 1,4 & \\
\hline ra putra & 0 & 0 & 0 & 0 & 3 & 1 & 4,24 \\
\hline $\begin{array}{l}\text { Novianti } \\
\text { Saputri }\end{array}$ & 4 & 4 & 4 & $\begin{array}{c}1,7 \\
6\end{array}$ & $\begin{array}{c}1,2 \\
6\end{array}$ & $\begin{array}{c}1,4 \\
4\end{array}$ & 4,46 \\
\hline
\end{tabular}

\begin{tabular}{|c|c|c|c|c|c|c|c|} 
& 4 & 2 & 8 & & & & \\
& 0 & 0 & 0 & & & & \\
\hline & 4 & 5 & 4 & & & & \\
Judistina & 5 &, &, & & & & \\
Tyas & 0 & 0 & 0 & 0 & 0 & 2 & 4,62 \\
\hline & 4 & 4 & 4 & & & & \\
&, &, &, & & & & \\
Sonny & 1 & 5 & 5 & 1,6 & 1,3 & 1,3 & \\
\hline & 0 & 0 & 4 & 5 & 5 & 4,34 \\
Fajar & 3 & 4 & 5 & & & & \\
Deddy & 7 & 5 & 0 & 1,4 & 1,3 & 1,5 & \\
Hidayah & 0 & 0 & 0 & 8 & 5 & 0 & 4,33 \\
\hline
\end{tabular}

Sumber : Hasil pengolahan data(2019)

Setelah di lakukan perhitungan untuk mendapatkan hasil akhir dan ranking dari setiap keryawan menggunakan aspek sikap kerja, kepribadian, tanggung jawab maka daftar nama keryawan perusahaan yang terbaik ditampilkan pada Tabel 18.

Tabel 18. Daftar Karyawan Terbaik

\begin{tabular}{|l|l|c|}
\hline No & \multicolumn{1}{|c|}{ Karyawan } & Hasil Akhir \\
\hline 1 & Judistina Tyas & 4,62 \\
\hline 2 & Novianti Saputri & 4,46 \\
\hline 3 & Sonny & 4,34 \\
\hline 4 & Fajar Deddy Hidayah & 4,33 \\
\hline 5 & Devin Baguskara putra & 4,24 \\
\hline
\end{tabular}

\section{KESIMPULAN}

Berdasarkan penelitian yang telah dilakukan untuk proses pemilihan karyawan terbaik pada PT.Surindo Murni Agung menggunakan metode profile matching dengan beberapa aspek kriteria yaitu: sikap kerja, kepribadian dan tanggung jawab, pengambilan keputusan menjadi menjadi lebih cepat dan akurat serta dapat dipertanggungjawabkan hasilnya.

\section{REFERENSI}

Haryani, \& Fitriani, D. (2019). Sistem Pendukung Keputusan Penentuan Karyawan Terbaik Pada Collection Pt. Panin Bank Menggunakan. 3(1), 2. Retrieved from http://e-jurnal. pelitanusantara.ac.id/index.php/mantik/article/ view/521 
Helilintar, R., Winarno, W. W., \& Fatta, H. Al. (2016). Penerapan Metode SAW dan Fuzzy Dalam Sistem Pendukung Keputusan Penerimaan Beasiswa in Decision Support System Scholarship. 3(2), 92. Retrieved from https://citec.amikom.ac.id/main/index.php/cite c/article/view/68

Hertyana, H. (2018). Sistem pendukung keputusan penentuan karyawan terbaik menggunakan metode topsis. 4(1), 43. Retrieved from http://ejournal.nusamandiri.ac.id/index.php/jit k/article/view/317

Heru, P. (2017). Penerapan Metode Profile Matching Dalam Sistem Pendukung Keputusan Penilaian Kinerja Karyawan Pada Pt . Hyundai Mobil Indonesia Cabang Kalimalang. XIV(1), 15. Retrieved from http://ejournal.nusamandiri. ac.id/index.php/techno/article/view/179
Hidayat, R. (2016). Menentukan Promosi Jabatan Karyawan Dengan Menggunakan Metode Profile Matching Dan Metode Promethee. 2(1), 59. Retrieved from http://ejournal.bsi.ac.id /ejurnal/index.php/ijse/article/view/667

Junaidi, A., \& Visella, F. (2017). Pemilihan Penerima Beasiswa Menggunakan Metode Profile Matching. Paradigma-Jurnal Komputer dan Informatika, 19(2), 118-126.

Nashrullah, M. I., Abdillah, G., \& Renaldi, F. (2015). Sistem Pendukung Keputusan untuk Rekomendasi Promosi Jabatan ... (Nashrullah dkk.). 196-201. 